supported by ODA.

British policy is to cut multilateral, special programme aid hardest, for the government's aim is to maintain direct core subscriptions to international agencies (such as the World Bank and the United Nations Development Programme), while stressing bilateral aid which is inevitably under closer British political and economic control.

Robert Walgate

\section{Armadillos fight leprosy}

The safety and ethics panel of the World Health Organization (WHO) is likely to agree within the next few months on immunization trials with a new leprosy vaccine made from the liver and spleen of infected armadillos. The trials would be conducted from January to September 1982 in the United States, United Kingdom and Scandinavia to avoid criticisms of uncontrolled drug testing in third world countries.

The objective will be to induce $85-90$ per cent immunity to the causative agent of leprosy (Mycobacterium leprae) as judged by immune reactions to lepromin, a preparation of killed $M$.leprae obtained from infected human ear-lobes.

The vaccine has been a long-standing objective of the WHO Special Programme for Research and Training in Tropical Diseases (TDR). The snag is that it depends on culturing the bug in armadillos, whose low body temperature allows growth of the organisms, and some have questioned whether it will ever be possible to breed enough armadillos to vaccinate the 2,000 million or so of the human population potentially at risk.

Dr Barry Blum of the Albert Einstein College of Medicine in New York, who heads the TDR leprosy immunization project, says, however, that armadillos are such prolific generators of M.leprae that the numbers should be sufficient. A mixed vaccine made from human tissue yields immunity with a single dose of $6 \times 10^{8}$ killed bacteria. An armadillo three years after infection produces about $2.5 \times 10^{12}$ bacteria in the liver and spleen. If the vaccine produced from them is as effective as the human one, each armadillo should yield 4,000 doses. WHO now has 250 animals used for research and the forthcoming trial, but there is a population of 10 million armadillos in the southern United States.

The adequacy of the supply depends directly on the dose required to produce immunity. One shot must be $85-90$ per cent effective to avoid the need for repeated injections. The availability of the vaccine would also depend on the efficiency of extraction from armadillo tissue, a problem which has been given to the Wellcome Laboratories in the United Kingdom to resolve. Then leprosy is such a slow-moving disease that proof in the field against infective organisms will take ten years.
US solar energy

\section{No silver lining}

\section{Washington}

The Solar Energy Research Institute at Golden, Colorado, has been flung further into limbo by the arrival of the new Administration, which is now trying to respond to a demand from the General Accounting Office that the objectives of the institute should be spelled out. Most probably the institute, once the spearhead of President Carter's ambition that a fifth of United States energy consumption at the end of the century should be solar energy, will be asked to concentrate on long-term research, abandoning the commercial demonstration of solar energy devices. The present budget of $\$ 130$ million is likely to be cut by a half, and between 100 and 200 of the present staff of 770 will probably lose their jobs.

The brief history of the institute, set up in 1977 and managed for the Department of Energy by the Mid-West Research Institute of Kansas, is a tale of muddle. Originally, there was to have been a staff of 1,200 engaged on long-term research, development and the commercial demonstration of devices able to win energy from the Sun. In part, the institute has been the victim of the success of some applications of solar energy. Solar water heaters, large and small, and small hydroelectric plants are multiplying throughout the United States - the Department of Energy is embarrassed by more than 1,000 applications from private companies and individuals to build hydroelectric plants. With the Administration committed to the view that commercial developments should be the responsibility of commercial organizations, not the government, the institute's demonstration programme has become vulnerable. So much seemed clear during a visit to Golden by officials of the Department of Energy last month.

Even when the axe falls, in the next few weeks, the rump of the institute is unlikely to be reassured about its future. Although the institute is now nearly four years old, the special building (on a 300-acre site offered by the Government of Colorado) seems as far off as ever. In a sharp letter to the Secretary of Energy at the end of April, the General Accounting Office asked that further design should be postponed until the department had decided what the longterm role of the institute should be, and that even the use of the 300 -acre site for experimental rigs should wait on this definition. One snag is that the offer of the site expires in April 1982.

The letter is scathing about the planning of the building. Although authority for a laboratory was included in the 1974 Solar Energy Act, the estimated cost of $\$ 132$ million (in 1978) was an unwelcome surprise. Successive Secretaries of Energy have sought to limit the cost of the buildings to $\$ 98$ million (in 1979) and $\$ 75$ million (in 1980). The General Accounting Office points out that the original scheme for making the building 80 per cent selfsufficient in its own energy requirements was based on the use of active and passive solar power devices which had not been proved and which were not all costeffective. Meanwhile the institute's staff camps out in rented of fice accommodation costing \$5 million a year, and has spent substantial sums on the conversion of offices to laboratories.

Since 1977, the institute's research programme has been trimmed by the removal of general responsibility for the exploitation of biomass, but it remains responsible for the use of methanol as a liquid fuel - a motor vehicle driven by hydrogen derived from the catalytic decomposition of methanol will be demonstrated later in the year. The institute is also confident that it will be able to produce silicon-based solar cells yielding power at a cost of 70 cents per watt by the end of this decade, roughly a tenth of the present cost of solar cells.

\section{European Space Agency \\ Delays in space}

For the second time this year, the European Space Agency (ESA) may be hamstrung by a change of plans within the United States National Aeronautics and Space Administration (NASA). This time, the possible casualty is Spacelab, ESA's manned space laboratory due to be launched on the space shuttle. Spacelab's first flight could be delayed, or its success reduced, if the Department of Defense persuades NASA to modify and thus delay the launch of the second of the two satellites intended to form the basis of a new data collection system.

The Tracking and Data Relay Satellite System (TDRSS) will eventually replace much of the worldwide network of tracking stations for relaying data from the space shuttle and satellites in low Earth orbit. Two tracking satellites, to be launched into geosynchronous orbits from early shuttle flights, were to transmit data from almost any position in a low Earth orbit to a central receiving station at White Sands, New Mexico. The original plan was to iaunch the first tracking satellite on the sixth shuttle flight, the second in June 1983 and Spacelab itself in September 1983. But now the Department of Defense has asked that extra coding should be built into the second satellite which could delay the launching until after that of Spacelab. One possibility is that the first Spacelab flight would be brought forward to June 1983 and the second tracking satellite launched only in September 1983.

If NASA accedes to this request, ESA would have the choice of either flying the first Spacelab payload with only one tracking satellite in service or of delaying the flight until the spring of 1984. One 